\title{
The Determinants of Listed Commercial Banks' Profitability in Vietnam
}

\author{
Hai Thanh PHAN' ${ }^{1}$, Tien Ngoc HOANG ${ }^{2}$, Linh Viet DINH ${ }^{3}$, Dat Ngoc HOANG ${ }^{4}$ \\ Received: August 01, 2020 Revised: September 20, 2020 Accepted: October 05, 2020
}

\begin{abstract}
The study investigates the factors affecting the profitability of listed commercial banks in Vietnam. Survey data for this research were collected from 10 Vietnamese listed commercial banks for the period from 2008 to 2018. In the study, we have built a model of econometric regression with the dependent variable being listed commercial banks' profitability results measured through ROA. The research methods used include descriptive statistics, IV regression and OLS regression analysis, and the authors carried out the model verification with Stata 14 software. The results showed that operating efficiency, loans size, retail loans ratio, state ownership, inflation rate, and GDP growth are factors that have a positive impact on profitability On the other hand, variables such as capital size, credit risk, liquidity risk, bank size, and revenue diversification are statistically insignificant; hence, these variables are not statistically adequate to indicate the influence of those independent variables to banks' profitability. The findings of this study suggest that the quality of assets should be considered in the context that bad debt risks come from lending heavily to the real estate sector. Meeting Basel II's capital compliance requirements is relatively difficult for small listed commercial banks compared to bigger listed commercial banks in Vietnam.
\end{abstract}

Keywords: Listed Commercial Banks, Profitability, OLS Regression, IV Regression, Vietnam

JEL Classification Code: L25, E44, O23, C23

\section{Introduction}

With the responsibility of connecting needs and capital supply, banks play an extremely important role in the economy. Therefore, the stability of the banking system is a prerequisite for an effective financial system and achieving economic growth. In particular, profitability is one of the key factors to ensure the stability of the banking system. With good profitability, the bank can benefit its

${ }^{1}$ First Author and Corresponding author. Associate Professor, Faculty of Accounting, Institute of Research and Development, Duy Tan University, Da Nang, Vietnam [Postal Address: 254 Nguyen Van Linh Street, Thanh Khe District, Da Nang City, 550000, Vietnam] Email: phanthanhhai@duytan.edu.vn

'Lecturer, Graduate School, Duy Tan University, Da Nang, Vietnam. Email: tienvjc@gmail.com

${ }^{3}$ Shinhan Bank, Ho Chi Minh City, Vietnam.

Email: linh.dv@vnp.edu.vn

${ }^{4}$ Indovina Bank Ltd. Head Office, Ho Chi Minh City, Vietnam.

Email: hngdat91@gmail.com

(c) Copyright: The Author(s)

This is an Open Access article distributed under the terms of the Creative Commons Attribution Non-Commercial License (https://creativecommons.org/licenses/by-nc/4.0/) which permits unrestricted non-commercial use, distribution, and reproduction in any medium, provided the original work is properly cited. own shareholders and continue to be a channel of capital to support other investments of individuals and organizations, thereby promoting the development of the whole economy. In contrast, with poor financial results, banks may face bankruptcy, creating/contributing to exacerbating financial crises, thereby leading to severe consequences for the global economy. Therefore, the interest in managing the profitability of banks is always a topic of concern for bank leaders, investors, depositors, and the government. Many studies on profitability and factors affecting the profitability of listed commercial banks have been carried out (Lipunga, 2014; Nshimiyimana \& Zubeda, 2017; Sufian \& Chong, 2008; Erina \& Lace, 2013; Menicucci \& Paolucci, 2016; Abel \& Le Roux, 2016; Mehta \& Bhavani, 2017); Hassan \& Bashir, 2003).

In Vietnam, research topics in the commercial banking sector are diverse, for example, Ha et al. (2019), Thinh et al. (2020), Diem and Tung (2020). Studies on the factors affecting the profitability of commercial banks have been published by many authors, including Minh and Canh (2015), Dung et al. (2015), Le (2017), Nguyen et al. (2018), Ngoc Nguyen (2019), Binh and Dung (2020). However, in Vietnam, according to the authors, the study of profits and factors affecting the profitability of the group of commercial banks listed in the period from 2008 to 2018 is not available. 
Through the research results, the authors make suggestions on policy implications to help managers improve the profits of listed commercial banks.

This research has the following objectives: (i) the overall study of the profitability of listed commercial banks in Vietnam, and their relationship to other important economic factors; (ii) presents the research model, with hypotheses including: research design, analysis, and discussion of the results; (iii) conclusions from the research also indicating points to improve for future research.

\section{Literature Review and Research Hypotheses}

Profitability is the norm that can be calculated in absolute or relative numbers via ratio. However, the benefits of calculating profitability ratios are that in a time-series study they can reduce inflation volatility (Rasiah, 2010). A variety of measures, including returns on assets (ROA), returns on equity (ROE), returns on deposits (ROD), and the profit margin (BTP/TA), are widely used to measure the profitability of a commercial bank (Burhonov, 2006). These factors are ROA and ROE, which are also the two most utilized ratios (Iqbal \& Molyneux, 2005).

\subsection{Foreign Research}

Previous studies about bank profitability are relatively large in number. However, studies are often conducted in developed markets, rather than in developing countries (Ayanda et al., 2013). Taken together, the two common groups of factors in the profitability studies of commercial banks are (i) bank-specific factors and (ii) external factors. Typical are some studies such as Erina and Lace's (2013) research arguing that the commercial banks profitability indicators of Latvian banks in the period 2006-2011 is affected by factors such as (i) operational efficiency, (ii) structure of asset portfolio; meanwhile, two factors: (i) capital and (ii) credit risk have a negative impact on ROA. If profitability is measured by ROE, then the linear relationship is positive with capital, while the negative relationship with (i) operational efficiency and (ii) credit risk is documented based on empirical evidence. The external factors in the research model are GDP growth rates having a positive relationship with profitability.

In addition, Menicucci and Paolucci (2016) assessed the relationship between profitability and endogenous factors of the 28 largest banks in European Union countries from 2006 to 2015. Empirical results support positive relationship between profitability and (i) capital adequacy ratio, (ii) bank size and (iii) deposit ratio. Meanwhile, asset quality has a negative effect on profitability. Based on the regression results, the study also gave some policy implications for enhancing the robustness and stability of the European banking sector.

Besides, Abel and Le Roux (2016) empirically studied the banking industry of Zimbabwe between 2009 and 2014 using the fixed effects panel regression models. The authors have shown that the profitability of banks of this country is largely determined by bank-specific factors. This statement confirms the role of banks' leaders in improving the profitability of their own banks. Factors like size of liquid assets, capital size, asset quality, and cost efficiency are backed by empirical evidence that they are positively associated with profitability. Based on this, the study recommends that banks in Zimbabwe can improve asset quality, cost management and liquidity management to achieve better financial performance.

Meanwhile, according to the study by Ozgur and Gorus (2016) on the deposit bank profitability of Turkish banks, two groups of bank-specific and macroeconomic factors are quantitatively analyzed (by the OLS method) to assess the level of impact on profitability over the 10-year period from 2006 to 2016. The results of the study show that the bank's profitability is influenced by: (i) capital size, (ii) asset quality, (iii) interest income to total assets ratio and (iv) central bank's interest rate. Meanwhile, the following four factors do not have significant linear relationship with profitability: (i) non-interest income to total assets ratio, (ii) market share, (iii) operating expense to total assets ratio, and (iv) exchange rate. The study also demonstrated the negative impact of the 2008 financial crisis on the profitability of banks in Turkey.

Mehta and Bhavani (2017) assessed the factors affecting the profitability of 19 commercial banks in the UAE from 2006 to 2013 using panel data regression analysis. The explanatory power of the model is quite strong with capability of explaining for more than $75 \%$ changes in total variance of profitability. Empirical research results have identified three factors that have a significantly positive impact on the bank's profitability, including: (i) cost efficiency, (ii) capital adequacy ratio, and (iii) asset quality.

\subsection{Domestic Research}

Regarding banking practices in Vietnam, a few studies have been conducted on the profitability of banks with different time periods and conclusions. The authors gathered and analyzed some of the following projects:

Minh and Canh (2015) studied the profitability of 22 Vietnamese commercial banks between 2007 and 2013. The regression results of the system generalized method of moments (SGMM) method show a positive relationship between income diversification and profitability. Other factors studied such as the ratio of outstanding loans to total assets (loans size), the ratio of customer deposits (structure 
of capital mobilization) and inflation have a positive relationship with the profitability of banks. Meanwhile, the bad debt ratio (credit risk), the ratio of equity/total assets (capital size), the ratio of operating expenses to income (cost efficiency) has a negative relationship with profitability. The study also stressed that no evidence was found about the impact of the size of total assets (bank size) and economic growth on the profitability of commercial banks in Vietnam.

Meanwhile, Dung et al. (2015) analyzed the profitability of 17 Vietnamese commercial banks between 2002 and 2013. The research results show that income from noncredit activities in general has a positive impact on banks' ROA. This study also demonstrates that the process of increasing the proportion of income from non-credit activities of Vietnamese commercial banks and its impact on profitability is still quite modest. Therefore, the prospect of deeper participation in non-credit activities of Vietnamese commercial banks is still quite large in the near future.

In addition, Le (2017) analyzed the factors that have a significant impact on the profitability of Vietnamese commercial banks from 2005 to 2015 using the SGMM method proposed by Arellano (2002). The research results have shown the direction of impact on the bank's profitability of key factors: bank size (negatively related), loan size (positively related), liquidity risk (negatively related), being more diversified (positively related), being listed on the stock exchange (positively related). Moreover, this study also shows that the lower the concentration level of the industry, the greater the financial efficiency will be achieved and the profit will be sustainable over time. Based on regression results, the study made some policy recommendations. Specifically, according to Le (2017), mergers and acquisitions activities involving a state-owned bank should be carefully analyzed before proceeding. It is also recommended that banks be facilitated to list on the stock exchange to increase information transparency. In terms of corporate governance, banks are recommended to improve and streamline their day-to-day operations as a basis for cost and profitability optimization. Non-interest activities need to be considered, especially for the retail segment. This income segment is expected to bring significant opportunities for retail segment to improve income.

Nguyen et al. (2018) used regression analysis method on a panel data of 13 Vietnamese commercial banks for the period from 2006 to 2015. As a result of the study, the following factors have a significant negative impact on the profitability of banks: (i) foreign shareholder's ownership ratio, (ii) cost to income ratio, and (iii) credit risk. Meanwhile, (i) state ownership, (ii) bank size, and (iii) macro factors such as GDP growth rate and inflation have no linear relationship with the bank's profitability. The remaining two factors in the study (including capital structure and liquidity risk) have a negligible impact.
Ngoc Nguyen (2019) studied the relationship between revenue diversification, risks and profitability of 26 Vietnamese commercial banks (from 2010 to 2018) using the generalized method of moment (GMM) method. Empirical results from the research model indicate an inverse relationship between revenue diversification and profitability. In particular, the author explains that the impact of revenue diversification on profit is mixed. Specifically, the greater the degree of revenue diversification, the more risks the bank will face, however, the sustainability of the revenue is improved. Overall, the negative effects are still greater than the positive effects.

Binh and Dung (2020) investigated the factors affecting the profitability of commercial banks in Asian developing countries, including Vietnam, Malaysia and Thailand. Authors used panel data of four entities; ten banks in Vietnam, eight banks in Malaysia, nine banks in Thailand and all 27 commercial banks from the period 2012 to 2016. As a result of the study, the most outstanding similarity is that all entities display a significantly negative relationship between operational risk and banking profitability. Likewise, the significantly negative influence of bank size to profitability is found on models of Vietnam and Thailand and no significant effect on the model of Malaysia. Meanwhile, the most controversial result comes up with the negative relationship between CAR and profitability indicators as well as the positive association between credit risk and banking profitability.

\section{Data and Research Methodology}

\subsection{Data}

To test the research hypotheses, the data used in quantitative analysis is information extracted from the financial statements of Vietnamese listed banks. These are all audited financial statements (by the four largest foreign auditing firms of Vietnam and the world, KPMG, PwC, Ernst \& Young, and Deloitte). These reports are prepared in accordance with Vietnamese accounting standards. The research period is eleven years (from 2008 to 2018). In the above period, there were 13 Vietnamese banks listed on HNX and HSX. However, only 10 banks were collected for analysis. The three banks outside the list are Saigon Hanoi Commercial Joint Stock Bank, National Citizen Commercial Joint Stock Bank, and Tien Phong Commercial Joint Stock Bank (with listed stocks, respectively SHB, NVB \& TPB). SHB was removed from the list of banks studied because of the unusual nature of income and asset structure of the bank. Specifically, during the research period, SHB was merged with HBB (Habubank). This led to SHB having to accept all the bad debts of HBB (the reason that this bank almost went bankrupt). Accordingly, the profits and assets of SHB 
since the time of merging HBB are no longer significant compared to the previous period. In the case of NVB, this bank is excluded because NVB is considered to be a weak bank in the industry, so it is different from the other banks in the list. Listed banks are all in the top of the industry. The same reason TPB was removed from the research list. Although the bank is currently developing well, it has been ranked weak by the SBV and needs to be restructured in 2011. The remaining macroeconomic data (GDP growth rate and inflation) are collected from the official announcement of the General Statistics Office of Vietnam.

\subsection{Research Methods}

\subsubsection{Research Model}

From the above studies, the authors conduct specific analysis to generate the following hypotheses and research models:

- Capital size has a positive relationship with banks' profitability (supported by Menicucci \& Paolucci, 2016; Abel \& Le Roux, 2016; Mehta \& Bhavani, 2017; however, inconsistent with Erina \& Lace, 2013). The Vietnamese government is very concerned about the banks maintaining their equity levels. Specifically, banks are encouraged by the SBV to take the initiative in raising equity levels and have a mandatory roadmap for this (through setting the minimum capital level). The reason for this incentive is that in banking activities, equity acts as a cushion to absorb losses. This is also the foundation for the bank to expand business operations and gain stable profits in the long term. Therefore, a positive relationship between equity size and profitability is expected in the Vietnamese banking industry.

- Operating efficiency (or cost efficiency) has a negative relationship with banks' profitability (supported by Nguyen et al., 2018; Minh \& Canh, 2015; however, inconsistent with Erina \& Lace, 2013; Abel \& Le Roux, 2016; Mehta $\&$ Bhavani, 2017). The opposite nature between the ratio of cost to revenue and profitability has been empirically proven in previous studies. Because direct costs reduce profits, if the bank can control operating costs efficiently, it will improve profitability. Moreover, suitable reducing operating costs will be the basis for banks to lower service prices (e.g., lending rates, fees, etc.), thereby helping to attract customers. The reduction in operating costs can come from better governance and the application of new technologies. Thus, the research expects a negative relationship between operating efficiency and profitability.

- Credit risk has a negative relationship with banks' profitability (supported by Erina \& Lace, 2013; Minh \& Canh, 2015; Nguyen et al., 2018). The loan portfolio with relatively safe loans (i.e., low credit risks) will help the bank avoid the risk of bad debts and only need to make a low provision for credit losses. This situation is often observed in developing countries. Thus, the research expects a negative relationship between credit risk and profitability in Vietnamese context.

- Liquidity risk has a negative relationship with banks' profitability (supported by Le, 2017; however, inconsistent with Abel \& Le Roux, 2016). Basically, assets with lower liquidity will have higher free-asset to get more opportunities of earning profit, due to no inclusion of a compensation fee for liquidity risk. Therefore, the research expects a negative relationship between liquidity risk and profitability.

- Revenue diversification has a positive relationship with banks 'profitability (supported by Minh \& Canh, 2015; Dung et al., 2015; Le, 2017). Banks now tend to want to increase the role of non-interest income (such as fees, commissions, etc.). The reason for this is that the profit gained is the actual cash flow (unlike interest income is accrued income, there is no actual cash flow into the bank). Moreover, increasing the proportion of non-interest income will help increase the diversity of types of revenue in the bank, thereby reducing risks through diversification. Therefore, a positive relationship between revenue diversification and profitability is expected in this research.

- State ownership has a relationship with banks' profitability (supported by Nguyen et al., 2018). Vietnam has four state-owned banks and all are the leading banks in terms of total assets and profits. By supporting the SBV in regulating monetary policy, these banks have just received outstanding incentives and advantages, and are also subject to certain restrictions. Therefore, the trend of the impact of state ownership on the bank's profitability is in both directions (favorable and unfavorable). In addition, stateowned enterprises in Vietnam are generally considered less effective than private ones. Therefore, state-owned banks could not avoid this characteristic. However, all is estimation and there is no theory for this factor. Therefore, the research expects a relationship between state ownership and profitability to make clear the relationship either negative or positive.

- Loans size has a positive relationship with banks" profitability (supported by Minh \& Canh, 2015; Le, 2017). Because lending is one of the key banking business and brings most of the profits to Vietnamese banks, this research expect a positive relationship with loans size.

- Bank size has a positive relationship with banks' profitability (supported by Menicucci \& Paolucci, 2016; however, inconsistent with Le, 2017). Previous studies have provided empirical evidence on the positive relationship between bank size and profitability. Large banks are said to face the risk of operating at large scale so they need to be more profitable than small banks. Moreover, large banks with stronger potential will be able to attract more customers, 
thereby creating more profits. The research expects a positive relationship between bank size and profitability.

- Lagged of profitability ( $\pi t-1)$ have a positive relationship with bank profitability (support by (Le, 2017). Profitability in previous year plays a supporting step for business of the next year. In the model, the coefficient $\beta 1$ of this variable presents the speed at which profits may adjust to long-run equilibrium (Athanasoglou et al., 2008). There is a high speed of adjustment in ROA in highly competitive market when $\beta 1$ is closer to 0 , meanwhile a very terrible speed of adjustment implying $\beta 1$ reach nearby 1 . It means that the industry is not competitive. Therefore, the research expects a positive relationship between lagged of profitability and profitability.

- GDP growth rate has a positive relationship with banks' profitability (supported by Erina \& Lace, 2013). In a wellgrowing economy, businesses expand production, consumers demand more shopping, therefore, financial intermediaries will work actively as an effective capital channel. The business situation of banks often has a close relationship with the health of the economy. The GDP growth index usually represents the good or bad state of an economy. Therefore, the research expects a positive relationship between GDP growth rate and profitability.

- Inflation rate has a relationship with banks' profitability (supported by Minh \& Canh, 2015). The level of inflation has an impact on interest rates - important indicators in the economy in general and the banking industry in particular. But the level of the impact of inflation on different types of interest rates is different. For banks, net interest income is the difference between lending rates and deposit rates. Therefore, the effect of inflation on the bank's profit (i.e., net interest income) depends on the specific fluctuations of the two interest rates due to inflation. The research expects a relationship between inflation rate and profitability to make clear the relationship either negative or positive.

The author's research model is:

$$
\begin{aligned}
\mathrm{ROA}= & \alpha+\beta_{1} * \text { RLLOANS }+\beta_{2} * \text { OPERATING_E } \\
& +\beta_{3} * \mathrm{SOCB}+\beta_{4} * \text { LOANS_SIZE }+\beta_{5} * \\
& \text { INFLATION }+\beta_{6} * \text { GDP_GR }+\varepsilon
\end{aligned}
$$

OPERATING_E explained by six instrument variables as following model to treat endogeneity problems:

$$
\begin{aligned}
\text { OPERATING_E }= & \delta+\delta_{1} * \text { CAPITAL_SIZE }+\delta_{2} * \\
& \operatorname{REVENUE\_ D~}+\delta_{3} * \text { CREDIT_RISK } \\
& +\delta_{4} * \text { LIQUIDITY_RISK }+\delta_{5} * \\
& \text { BANK_SIZE }+\delta_{6}^{*} \pi \bar{i}_{, \mathrm{t}-1}+\mu
\end{aligned}
$$

Beside IV regression, the study also runs OLS to have comparison:

$$
\begin{aligned}
\mathrm{ROA}= & \alpha+\beta_{1} * \text { RLLOANS }+\beta_{2} * \text { CAPITAL_SIZE }+\beta_{3} \\
& * \text { OPERATING_E }+\beta_{4} * \text { CREDIT_RISK }+\beta_{5} * \\
& \text { LIQUIDITY_RISK }+\beta_{6} * \text { REVENUE_D }+\beta_{7} * \\
& \text { SOCB }+\beta_{8} * \text { LOANS_SIZE }+\beta_{9} * \text { BANK_SIZE } \\
& +\beta_{10} * \pi i_{, t-1}+\beta_{11} * \text { INFLATION }+\beta_{12} * \text { GDP_GR } \\
& +\varepsilon
\end{aligned}
$$

\subsubsection{Research Methods}

After processing the group survey, the authors carried out the model verification with Stata 14 software. Proposed theoretical research model and research hypotheses are tested both OLS and IV regress. Due to the structure of panel data used in this study, a two-stage least square (2SLS) by IV regression is used for suitable panel data and small scales of observation in order to test hypothesizes. The purpose of 2SLS is to control for two basic problems: unobserved heterogeneity and the endogeneity problems (Söderbom, 2009). The 2SLS estimator accounts for unobserved heterogeneity and for the persistence of the dependent variable. Therefore, this estimator yields consistent estimations of the parameters. The estimated coefficients are more efficient because a sample set of instruments is used. For the endogeneity problems, following the paper of Le (2017), the system 2SLS estimator uses instruments including revenue diversification, lagged of profitability, credit risk, liquidity risk, capital size and bank size to treat endogenous problem. In addition, Sargan tests and the test for over-identifying restrictions (Wooldridge, 2002) are used to make sure the high confident level of result. If the null hypothesis of Sargan test is rejected, the instruments do not meet the required orthogonality conditions.

\section{Results}

\subsection{Descriptive Analysis}

The data of 10 Vietnamese listed banks for the period from 2008 to 2018 are completed with total number of observations of 110 (see Table 1).

Descriptive statistics analysis of all variables is presented in Table 2.

In the period from 2008 to 2018, 10 Vietnamese listed banks have an average profitability of $1.14685 \%$. This means that for every 100 units of total assets, the average bank generates 0.0114685 units of profit after tax. The standard deviation of profitability is quite large, indicating a significant difference between banks. The lowest profitability is $0.027 \%$ of STB in 2016 because this bank got low interest income and suffered from higher expense also in this year. Besides that, the highest of profitability is $2.87 \%$ of TCB in 2018. 
Table 1: Summary of analyzing commercial banks

\begin{tabular}{|l|c|l|}
\hline No & Listed ticker & \multicolumn{1}{c|}{ Official name } \\
\hline 1 & VPB & Vietnam Prosperity Joint Stock Commercial Bank \\
\hline 2 & MBB & Military Commercial Joint Stock Bank \\
\hline 3 & VCB & Bank for Foreign Trade of Vietnam \\
\hline 4 & HDB & Ho Chi Minh Development Joint Stock Commercial Bank \\
\hline 5 & BID & Joint Stock Commercial Bank For Investment And Development Of Vietnam \\
\hline 6 & CTG & Vietnam Joint Stock Commercial Bank for Industry and Trade \\
\hline 7 & ACB & Asia Commercial Bank \\
\hline 8 & STB & Sai Gon Thuong Tin Commercial Joint Stock Bank \\
\hline 9 & EIB & Vietnam Commercial Joint Stock Export Import Bank \\
\hline 10 & TCB & Vietnam Technology and Commercial Joint Stock Bank \\
\hline
\end{tabular}

Table 2: Descriptive Statistics Sample

\begin{tabular}{|l|c|c|c|c|c|}
\hline Variables & Observations & Mean & Standard deviation & Min & Max \\
\hline ROA & 110 & 0.0114685 & 0.006029 & 0.0002797 & 0.0287069 \\
\hline RLLOANS & 110 & 0.3543753 & 0.1592843 & 0.096277 & 0.7846017 \\
\hline CAPITAL_SIZE & 110 & 0.0816772 & 0.030783 & 0.0404839 & 0.2662105 \\
\hline OPERATING_E & 110 & 0.4662011 & 0.1204701 & 0.2500016 & 0.8695538 \\
\hline CREDIT_RISK & 110 & 0.013723 & 0.0056497 & 0 & 0.0370178 \\
\hline LIQUIDITY_RISK & 110 & 0.3181555 & 0.1023915 & 0.1102718 & 0.548564 \\
\hline REVENUE_D & 110 & 0.4339348 & 0.2152901 & 0 & 0.9528747 \\
\hline SOCB & 110 & 0.3 & 0.4603549 & 0 & 1 \\
\hline LOAN_SIZE & 110 & 0.5621002 & 0.1155696 & 0.3075548 & 0.7530163 \\
\hline BANK_SIZE & 110 & 19.14655 & 0.9294837 & 16.07288 & 20.99561 \\
\hline GDP_GR & 110 & 0.0610493 & 0.0059173 & 0.0524737 & 0.0707579 \\
\hline INFLATION & 110 & 0.0811694 & 0.0657533 & 0.008786 & 0.2311632 \\
\hline
\end{tabular}

From 2008 to 2018, retail lending segment developed strongly. The retail credit share of outstanding balance increased significantly year-by-year from $9.6 \%$ of $\mathrm{VCB}$ in 2008 to $78.5 \%$ of VPB in 2016 with the standard deviation of 0.16 .

Bank size is calculated by natural logarithm of total asset. Therefore, this figure fluctuates between 16.07 in 2008 of HDB and 20.99 in 2018 of BIDV with the mean of 19.06 and the standard deviation of 1.03 .

Capital size move between the minimum of 0.04 from $\mathrm{ACB}$ in 2011 to the maximum of 0.27 from EIB to 2008 and the mean value is 0.08 . There is a big gap for this figure with the standard deviation 0.03 .

The ratio of cost to income of banks during the period time has large changes. The minimum is 0.25 belonging to MMB in 2008 and the maximum is 0.87 belonging to STB in 2018 with the standard deviation of 0.12 and the average of 0.46 . The more expand in business will get higher cost to income ratio because a bank run large scale need more expense in marketing, operation.

Credit risk has the smallest value of 0 in year from bank because there is no provision for loans in this year of bank. The bank with the biggest value of credit risk of 0.04 in 2008 is VCB. This indicator has the mean of 0.013 and the standard deviation of 0.006 .

Similarly, Liquidity risk has the smallest value of 0.11 in 2017 from ACB. VPP has the biggest value of liquidity risk of 0.55 in 2011. Each bank has different level of liquidity risk. This indicator has the mean of 0.013 and the standard deviation of 0.006 .

Revenue Diversion fluctuates variably from 0 to 1 . The minimum is 0 because VPB, MBB, HDB and ACB have no non-interest income in the year of 2007, 2008, 2011 and 2012, respectively. The maximum is 0.95 because HDB 
collects income mainly from non-interest activity in the year of 2009. Thus, the mean is 0.43 and the standard deviation is 0.22 .

Loan size fluctuates from the bottom at 0.31 of HDB in 2011 to 0.75 of BID in 2018. The mean is 0.56 and the standard deviation is 0.12 .

About macro-economic indicators, GDP increased from 0.052 in 2012 to 0.071 in 2007. Similarly, inflation rate increased from 0.008 in 2015 to 0.23 in 2008 because the financial crisis. GDP's mean is 0.06 and the standard deviation is 0.006 . The inflation rate mean is 0.08 and the standard deviation is 0.063 .

\subsection{Correlation Analysis}

The values of correlation coefficients will be in the range $[-1 ;+1]$. In particular, for values less than zero, a negative linear relationship is implied between the two variables involved. Conversely, values greater than zero indicate a positive relationship. Extreme values like $0,-1$ and +1 denote no linear relationship, perfect negative linear relationship and perfect positive linear relationship. The closer the two extreme values $(-1$ and +1$)$, the closer it reflects the strength of the linear relationship. The relationship between the two variables "ROA" and "OPERATING E" should be noted. In particular, the cost to income ratio is used to represent the variable OPERATING E. The larger the cost to income ratio means the lower the operating efficiency. Therefore, if the experimental result is a negative correlation efficient $(-0.7174)$ between OPERATING_E and ROA, then this implies a positive relationship between operating efficiency and profitability. Moreover, the Liquidity Risk and Loans Size have a strong correlation with the index of -0.7872 that the bank with large scale of loan has weak ability of liquidity. Also, there is a negative relationship between ROA and Retail Loan Share with correlation index -0.0855 (see Table 3).

\subsection{Regression Results}

This section presents the findings from the econometric results on the factors affecting bank profitability in Vietnam. The sections cover the regression results from the model used in this study. The regression result is presented in Table 4 and 5. As it can be seen from the table, the model presents the OLS R-square statistics and the IV regress 2SLS R-square statistics with $83.01 \%$ and $57.47 \%$ respectively. That means the changes in the independent variables are significant to explain the changes in the dependent variables. Therefore, variables used in the regression model in this study are good explanatory determinants of banks' profitability in Vietnam.

Table 3: Independent variable correlation matrix

\begin{tabular}{|c|c|c|c|c|c|c|c|c|c|c|c|}
\hline & ષ্র & 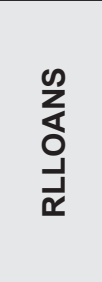 & 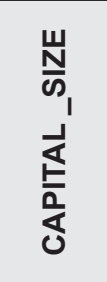 & 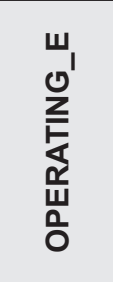 & 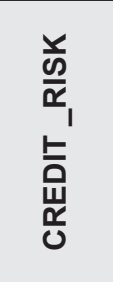 & 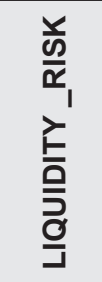 & 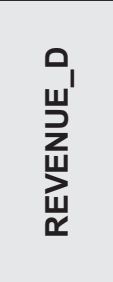 & $\begin{array}{l}\text { ற } \\
\text { O̊ }\end{array}$ & $\begin{array}{l}\text { U } \\
\frac{N}{\omega} \\
z \\
z \\
\end{array}$ & 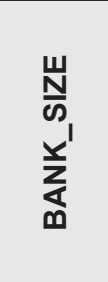 & $\begin{array}{l}\frac{\alpha}{0} \\
\text { । } \\
0 \\
0\end{array}$ \\
\hline ROA & 1.000 & & & & & & & & & & \\
\hline RLLOANS & -0.085 & 1.000 & & & & & & & & & \\
\hline CAPITAL SIZE & 0.273 & 0.176 & 1.000 & & & & & & & & \\
\hline OPERATING_E & -0.761 & 0.424 & -0.121 & 1.000 & & & & & & & \\
\hline CREDIT_RISK & 0.125 & -0.541 & -0.139 & -0.231 & 1.000 & & & & & & \\
\hline $\begin{array}{l}\text { LIQUIDITY_ } \\
\text { RISK }\end{array}$ & 0.410 & -0.215 & 0.106 & -0.434 & 0.167 & 1.000 & & & & & \\
\hline REVENUE_D & 0.233 & 0.069 & 0.185 & -0.175 & 0.030 & 0.023 & 1.000 & & & & \\
\hline SOCB & -0.132 & -0.676 & -0.398 & -0.215 & 0.446 & -0.139 & 0.018 & 1.000 & & & \\
\hline LOAN_SIZE & -0.323 & -0.115 & -0.132 & 0.230 & 0.069 & -0.787 & -0.073 & 0.486 & 1.000 & & \\
\hline BANK_SIZE & -0.154 & -0.412 & -0.530 & -0.074 & 0.314 & -0.381 & -0.093 & 0.680 & 0.527 & 1.000 & \\
\hline GDP_GR & 0.020 & 0.255 & -0.156 & -0.015 & -0.087 & -0.330 & -0.026 & -0.000 & 0.284 & 0.391 & 1.000 \\
\hline INFLATION & 0.303 & -0.189 & 0.210 & -0.258 & 0.060 & 0.436 & -0.026 & 0.000 & -0.372 & -0.438 & -0.376 \\
\hline
\end{tabular}


Table 4: OLS Regression Result

\begin{tabular}{|l|c|c|c|c|c|c|}
\hline ROA & Coef. & Std. & $\mathbf{Z}$ & P >z & \multicolumn{2}{c|}{ [95\% Conf. Interval] } \\
\hline RLLOANS & .0084296 & .0029129 & 2.89 & 0.005 & .0026399 & .0142193 \\
\hline CAPITAL_SIZE & .0220738 & .0144889 & 1.52 & 0.131 & -.0067244 & .050872 \\
\hline OPERATING_E & -.0280436 & .0035098 & -7.99 & 0.000 & -.0350198 & -.0210674 \\
\hline CREDIT_RISK & .0309198 & .0614575 & 0.50 & 0.616 & -.0912337 & .1530733 \\
\hline LIQUIDITY_RISK & .0074334 & .0053331 & 1.39 & 0.167 & -.0031668 & .0180335 \\
\hline REVENUE_D & .0028339 & .0015138 & 1.87 & 0.065 & -0001749 & .0058426 \\
\hline SOCB & -.0025774 & .0012609 & -2.04 & 0.044 & -.0050835 & -.0000712 \\
\hline LOAN_SIZE & .0166196 & .0052828 & 3.15 & 0.002 & .0061195 & .0271197 \\
\hline BANK_SIZE & -.0000797 & .0006447 & -0.12 & 0.902 & -.0013612 & .0012018 \\
\hline L.ROA & .04383683 & .0684785 & 6.40 & 0.000 & .030226 & .5744767 \\
\hline INFLATION & .0148913 & .0074233 & 2.01 & 0.048 & .0001367 & .0296459 \\
\hline GDP_GR & .0476039 & .0569749 & 0.84 & 0.406 & -.0656399 & .01608477 \\
\hline Cons & -.0003216 & .0133883 & -0.02 & 0.981 & -.0269322 & .026289 \\
\hline Number of obs & \multicolumn{3}{|c|}{100} & Adj R-squared & & 0.8067 \\
\hline F & \multicolumn{2}{|c|}{0.83 .43} & \multicolumn{2}{c|}{ Rob > F } & & .0000 \\
\hline R-squared & \multicolumn{7}{|c|}{ Root MSE } & & .00256 \\
\hline
\end{tabular}

Table 5: IV regress Regression result

\begin{tabular}{|l|c|c|c|c|c|c|}
\hline ROA & Coef. & Std. & Z & P >z & \multicolumn{2}{c|}{ [95\% Conf. Interval] } \\
\hline OPERATING_E & -.0672553 & .0059366 & -11.33 & 0.000 & -.0788908 & -.0556198 \\
\hline RLLOANS & .015241 & .0043427 & 3.51 & 0.000 & .0067293 & .0237526 \\
\hline GDP_GR & -.1641805 & .0789153 & -2.08 & 0.037 & -.3188517 & -.0095094 \\
\hline INFLATION & .0188408 & .0097055 & 1.94 & 0.052 & -.0001817 & .0378633 \\
\hline SOCB & -.0049745 & .0013487 & -3.69 & 0.000 & -.0076179 & -.0023312 \\
\hline LOAN_SIZE & .0187794 & .0052073 & 3.61 & 0.000 & .0085733 & .0289854 \\
\hline Cons & .0371144 & .0054988 & 6.75 & 0.000 & .0263369 & .047892 \\
\hline Number of obs & \multicolumn{2}{|c|}{100} & \multicolumn{2}{c|}{ Wald chi2 } & \multicolumn{2}{c|}{163.09} \\
\hline Sargan chi2 & \multicolumn{2}{|c|}{$0.77333(p=0.7349)$} & \multicolumn{2}{c|}{ Rob > Chi2 } & \multicolumn{2}{c|}{.00000} \\
\hline R-squared & \multicolumn{3}{|c|}{0.5747} \\
\hline
\end{tabular}

Notes : Standard errors in parentheses ${ }^{* * *} p<0.01,{ }^{* *} p<0.05,{ }^{*} p<0.1$.

Based on the regression result, retail loans ratio, operating efficiency, state ownership, loans size, GDP growth and the inflation rate are statistically significant variables. On the other hand, variables such as capital size, credit risk, liquidity risk, bank size, and revenue diversification are statistically insignificant; hence, these variables are not statically adequate to indicate the influence of those independent variables to banks' ROA.

While GDP growth shows a significant and negative coefficient against banks' profitability, the inflation rate shows a positive and significant coefficient against banks' ROA. Among all the significant variables, retail loans ratio (RLLOANS), operating efficiency (OPERATING_E), state ownership (SOB), and loan size (LOANS_SIZE) were significant at $1 \%$ significance level since the $\mathrm{p}$-value for all those variables were less than 0.01 . Besides, the result also indicates that the coefficient by OLS of operating efficiency (OPERATING_E), state ownership (SOCB), and GDP growth (GDP) against banks' profitability were negatively with the coefficient are negative $0.06726,0.00497$ and 
0.001642 , respectively. This result indicates that there was an inverse relationship between these variables and bank's profitability.

In comparison, variables like retail loans, loan size, and the inflation rate had a positive relationship with ROA. This shows a direct relationship between these independent variables and banks' profitability. In general, of all the 13 independent variables used in this study, only retail loans ratio, loans size, state ownership, GDP growth and the inflation rate are good explanatory determinants of profitability.

\section{Discussion}

In order to select the suitable model for the study, Sargan test was run. The result shows that P-value from Sargan test is 73.49 , so the study accepts the regression results as suitable and significant in explanatory (Table 5)

Operating efficiency (OPERATING_E) shows a significant negative impact on banks'ROA with the coefficient of negative 0.06726. As discussed in the literature (Nguyen et al., 2018; Minh \& Canh, 2015), management performance is reflected in the operating efficiency ratio; therefore, when the management performance is poor, higher cost will hurt banks' profitability. The result is in line with previous studies in Vietnam. Operating efficiency is a significant factor for commercial banks, especially those focusing more on retail segments as the ability to lower operating costs will allow banks to spend more resources on services diversification and technology application.

As indicate in the Table 3 , the positive and significant sign on the ratio of total outstanding retail loans to total loans is found to be completely in line with the expectation and suggestions from Dinc (2017), Hirtle and Stiroh (2007) and Hassan et al. (2012). This is also supported by the result for the loans size (LOANS_SIZE). This study finds out a significant and positive coefficient against ROA. This positive relationship is in line with the expectation and supports the earlier finding of by Minh and Canh (2015) and Le (2017) that with medium competition in the credit market, lending is the main source of profits. This is especially true in developing economies like Vietnam where traditional lending activities is a main business of banks. This finding could be especially driven by the income generated by less risky, medium volatile and realizable trading activities that most of commercial banks observed in this study represent as a primary source of non-interest income.

Interestingly, the coefficient of GDP growth against ROA shows an unexpectedly negative and significant sign against banks' ROA (inconsistent with Erina and Lace, 2013). Generally, it is expected that GDP growth rate would link to positive effect to the credit market as an increase in GDP lead to more demands of product and services. However, the negative result in GDP growth rate and banks' ROA could explain the trend in shifting focus from commercial banks to retail lending activities. Looking at the investment as percentage of GDP at current price from 2008 to 2018 (table below), it is clear that the trend is down, which indicates that business is not looking to expand. Therefore, the demand for industrial credit has been dried up, which might suggest why the growth in GDP might hurt commercial banks in Vietnam if they are too concentrating on corporate lending segments.

In addition, the sign of the inflation rate is found to be completely positive and significant related to banks' ROA. The result reflects the finding from Minh and Canh (2015) in which it shows a relationship between the inflation rate and banks' performance. It is also interesting to note that while the study expects there is a positive relationship between state ownership and profitability in Vietnam context, the regression result for the efficient of state ownership against ROA is negative and significant. Possibly, it might suggest that in the context of a more focus on retail business activities by commercial banks in Vietnam, the more controlling decisions on the interest rate will weaken the ability to generate profits of commercial banks. As of the economic context in Vietnam is still considered as a developing economy and still enjoying benefits from higher inflation rate, the economy will see a strong rise in consumer spending and in the population of middle class. Hence, this will benefit commercial banks in Vietnam in their decision to shift their development towards retail segments until the economy hits a certain point where higher inflation rate does not support higher growth in the profitability. On the other hand, the negative coefficient of GDP growth against banks' ROA might suggest that the resources allocation of higher GDP growth is not effective for commercial banks relying on traditional lending activities. One of the main reasons that can possibly explain to this issue is that the growth of GDP might be dependent heavily from government spending rather than investment from private sector. Therefore, this might explain the trending in the credit market in Vietnam in which banks are shifting their concentration on retail customers who can suffer from higher interest rate rather than heavily depending on corporate customers.

As expected, the state ownership (SOB) variable shows a significant and negative coefficient against banks' ROA at negative 0.00497 . This is in fact in line with the study of Nguyen et al. (2018). Although it is understandable that with supports from the state, banks might have some kinds of advantage in the credit market. However, it is not actually beneficial if banks are more focusing on retails business activities segments. For example, when the government has more control, banks might have to support to effectively implement monetary policies during time in need. In most cases, it is to pay more resources to support the corporate customers; as a result, banks have less resource to sustain 
and grow the retail segments in which it actually boosts their profit as shown in the regression result for the retail loans ratio variable.

Finally, it is interesting to note that the study does not find significant results for variables such as credit risk, liquidity risk, capital size, bank size, and revenue diversification. Although the study does not conclude that these variables are not affecting banks' profitability, the study did not find out significant explanatory sign of those variables to the list of commercial banks examined.

\section{Conclusions}

The contribution of the banking industry to Vietnam's economic growth (especially after 1990) is undeniable. However, with the increasingly development and close association with the economy of the banking industry, it is especially important to monitor the stability of the industry. In the coming period, in particular, in 2020, Vietnam's banking industry will have to face a series of obstacles, such as improving asset quality, increasing equity size, and improving profitability and competitiveness. The most prominent trend in the industry is to increase the proportion of non-interest income in the income structure; however, net interest income is still the main driver of profit. Therefore, the quality of assets should be considered in the context that bad debt risks come from lending heavily to the real estate sector. Meeting Basel II's capital compliance requirements is relatively difficult for small banks compared to bigger banks.

This study analyzes the factors affecting the profitability of listed banks in Vietnam in terms of bank characteristics and macroeconomic factors. Quantitative research data included 110 observations of ten banks listed in Vietnam from 2008 to 2018. With return after tax to total assets as the dependent variable, the model explain the impacts of main indicators including operating efficiency, loan size, retail loans share, state ownership, inflation rate, and GDP. Specially, the developments of retail loans in recent years give the effects to profitability of banks. Even contribution, this study has a limited dataset so that the research covers 10 listed banks. For further research, the dataset should be expanded and cover all Vietnamese banks to make sure that banking market in Vietnam is evaluated completely

\section{References}

Abel, S., \& Le Roux, P. (2016). Determinants of banking sector profitability in Zimbabwe. International Journal of Economics and Financial Issues, 6(3), 845-854.

Athanasoglou, P. P., Brissimis, SN. \& Delis, M. D. (2008). Bankspecific, industry-specific and macroeconomic determinants of bank profitability. Journal of International Financial
Markets, Institutions and Money, 18(2), 121-136. https://doi. org/10.1016/j.intfin.2006.07.001

Arellano, M. (2002). Sargan's instrumental variables estimation and the generalized method of moments. Journal of Business \& Economic Statistics, 20(4), 450-459. https://doi. org/10.1198/073500102288618595

Ayanda, A. M., Christopher, E. I., \& Mudashiru, M. A. (2013). Determinants of banks' profitability in developing economy: evidence from Nigerian banking industry. Interdisciplinary Journal of Contemporary Research in Business, 4(9), 155-181.

Burhonov, J. (2006). Islamic banking operations of commercial banks under Islamic Banking scheme (IBS) of Malaysia: The performance analysis. Master Thesis. Thammasat University Bangkok, Thailand.

Binh, T. T. D., \& Dung, P. N. (2020). Determinants of Profitability in Commercial Banks in Vietnam, Malaysia and Thailand. Journal of Asian Finance, Economics and Business, 7(4), 133143. https://doi.org/10.13106/jafeb.2020.vol7.no4.133

Dinc, Y. (2007). The Effect of Retail Loans on Bank Profitability A Comparative Empirical Analysis. Turkish Journal of Islamic Economics, 1(5), 19-34. Available at: https://mpra.ub.unimuenchen.de/id/eprint/85332

Diem, T. T. L, \& Tung, T. D. (2020). The Effect of Lending Structure Concentration on Credit Risk: The Evidence of Vietnamese Commercial Banks. Journal of Asian Finance, Economics and Business, 7(7), 59-72. https://doi.org/10.13106/jafeb.2020. vol7.no7.059

Dung, L. C., Thuan, N. T., \& Tin, P. Q. (2015). Study the impact of income from non-credit activities on the profitability of Vietnamese commercial banks. Journal of Economic Development, 26(6), 23-39.

Erina, J., \& Lace, N. (2013). Commercial banks profitability indicators: empirical evidence from Latvia. IBIMA Business Review, 2013(2013), 27-36. DOI: 10.5171/2013.873515

Hasan, I., Schmiedel, H., \& Song, L. (2012). Returns to retail banking and payments. Journal of Financial Services Research, 41(3), 163-195. https://doi.org/10.1007/s10693-011-0114-y

Hassan, M. K. \& Bashir, A. (2003). Determinants of Islamic banking profitability.Paper presented at the ERF Tenth Annual Conference, Marrakesh, Morocco, 16-18 December. Doi: 10.3366/edinburgh/9780748621002.003.0008

Hirtle, B. J., \& Stiroh, K. J. (2007). The return to retail and the performance of US banks. Journal of Banking \& Finance, 31(4), 1101-1133. https://doi.org/10.1016/j.jbankfin.2006.10.004

Iqbal, M. \& Molyneux, P. (2005). Development of the Islamic Banking Model. In: Thirty Years of Islamic Banking. Palgrave Macmillan Studies in Banking and Financial Institutions, London, UK: Palgrave Macmillan.

Le, T. (2017). The determinants of commercial bank profitability in Vietnam. Available at SSRN: http://dx.doi.org/10.2139/ ssrn.3048571 
Lipunga, A. M. (2014). Determinants of profitability of listed commercial banks in developing countries: Evidence from Malawi. Research Journal of Finance and Accounting, 5(6), 41-49.

Mehta, A., \& Bhavani, G. (2017). What determines banks' profitability? Evidence from emerging markets-the case of the UAE ban king sector. Accounting and Finance Research, 6(1), 77-88.

Menicucci, E., \& Paolucci, G. (2016). The determinants of bank profitability: empirical evidence from European banking sector. Journal of Financial Reporting and Accounting, 14(1), 86-115. https://doi.org/10.1108/JFRA-05-2015-0060

Minh, H. T. H., \& Canh, N. (2015). Income diversification and factors affecting the profitability of Vietnamese commercial banks. Banking Technology Review, $106+107,13-23$.

Ha, M. N., Cuong, N., Trung, T. N., \& Luan, V. N. (2019). The Effects of Job Crafting on Work Engagement and Work Performance: A Study of Vietnamese Commercial Banks. Journal of Asian Finance, Economics and Business, 6(2), 189201. https://doi.org/10.13106/jafeb.2019.vol6.no2.189

Ngoc Nguyen, K. (2019). Revenue diversification, risk and bank performance of Vietnamese Commercial Banks. Journal of Risk and Financial Management, 12(3), 138. https://doi. org $/ 10.3390 / \mathrm{jrfm} 12030138$

Nguyen, D. T., Ta, H. T., \& Nguyen, H. T. D. (2018). What determines the profitability of Vietnam commercial banks?.
International Business Research, 11(2), 231-245. https://doi. org/10.5539/ibr.v11n2p231

Nshimiyimana, Y. C., \& Zubeda, M. A. (2017). The influence of economic factors on profitability of commercial banks. International Journal of Management and Applied Science, 3(1), 14-18.

Ozgur, O., \& Gorus, M. S. (2016). Determinants of deposit bank profitability: evidence from Turkey. Journal of Applied Economics and Business Research, 6(3), 218-231.

Rasiah, D. (2010). Review of literature and theories on determinants of commercial bank profitability. Journal of Performance Management, 23(1), 23-49.

Söderbom, M. (2009). Applied Econometrics Lecture 2: Instrumental variables, 2SLS and GMM. Available at: http:// www.soderbom.net/lec2n_final.pdf

Sufian, F., \& Chong, R. R. (2008). Determinants of bank profitability in a developing economy: empirical evidence from the Philippines. Asian Academy of Management Journal of Accounting \& Finance, 4(2), 91-112.

Thinh, Q. T., Anh, H. L., \& Dung, K. N. N. (2020). Relationship between Ownership Structures and Earnings Management Behavior in Vietnamese Commercial Banks. Journal of Asian Finance, Economics and Business, 7(9), 401-407. https://doi. org/10.13106/jafeb.2020.vol7.no9.401

Wooldridge, J. M. (2002) Econometric Analysis of Cross Section and Panel Data (2nd ed.), Cambridge, MA: The MIT Press. 